\title{
Comparisons of Akathisia and Restless Legs Syndrome: An Electrophysiologic Study
}

\author{
Akatizi ve Huzursuz Bacaklar Sendromunun Karşılaştırılması: \\ Elektrofizyolojik Bir Çalışma
}

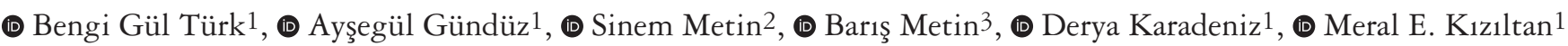 \\ ${ }^{1}$ Istanbul University Cerrahpasa Faculty of Medicine, Department of Neurology, Istanbul, Turkey \\ ${ }^{2}$ Istanbul University Cerrahpasa Faculty of Medicine, Department of Psychiatry, Uskudar University Faculty of Medicine, \\ Department of Psychology, Istanbul, Turkey \\ ${ }^{3}$ Istanbul University Cerrahpasa Faculty of Medicine, Department of Neurology, Uskudar University Faculty of Medicine, Department of \\ Psychology, Istanbul, Turkey
}

\begin{abstract}
Objective: There are clinical similarities between akathisia and restless legs syndrome (RLS). Thus, we aimed to investigate the functional changes of the brainstem and its rostral connections in akathisia in comparison with RLS.

Materials and Methods: Seven patients with akathisia were included in the study. We also included a group of patients with RLS ( $\mathrm{n}=14$ ), and a control group was formed including healthy volunteers $(\mathrm{n}=39)$. Blink reflex $(\mathrm{BR})$, auditory startle reflex (ASR), and somatosensory startle (SSS) reflexes were studied in all participants. Onset latency, probability of response, amplitude, pattern and duration of responses were compared between the 3 groups.

Results: Mean onset latencies of bilateral R2 and R2c were longer in the akathisia group compared with patients with RLS and healthy individuals. The mean latencies of responses after auditory stimulation were similar among the groups. The total ASR probability was higher in the akathisia and RLS groups compared with healthy subjects and this difference showed borderline significance $(\mathrm{p}=0.047)$. Duration of responses after auditory stimulation was longer in the akathisia group. Presence and latency of SSS were similar among the three groups.

Conclusion: Longer-onset latencies and the higher probability of ASR in the akathisia group suggest that there is a hypodopaminergic state in this group. On the other hand, the longer latencies of R2-BR in patients akathisia suggest a delayed transmission in its pathway, indirectly showing involvement of serotoninergic pathways in the absence of a structural lesion. Thus, in akathisia, there are findings suggestive of serotoninergic involvement, differing from RLS, whereas findings attributed to dopaminergic deficits were quite similar to patients with RLS.
\end{abstract}

Keywords: Akathisia, restless legs syndrome, brainstem reflexes, blink reflex, auditory startle reflex

$\ddot{\mathbf{O z}}$

Amaç: Akatizi ile huzursuz bacaklar sendromu (HBS) arasında klinik benzerlikler bulunmaktadır. Bu nedenle, akatizideki beyin sapı ve rostral bağlantılarının fonksiyonel değişikliklerini HBS’ye kıyasla araştırmayı amaçladık.

Gereç ve Yöntem: Akatizisi bulunan yedi hasta çalışmaya dahil edildi. Ayrıca HBS tanısı olan (n=14) hastalardan oluşmuş bir grup ve sağlıklı gönüllülerden $(\mathrm{n}=39)$ oluşan bir kontrol grubu oluşturuldu. Tüm katılımcılarda göz kırpma refleksi (GKR), işitsel irkilme refleksi (İ̈R) ve somatosensoryal irkilme (SSİ) refleksleri çalışıldı. Yanıtların başlangıç latansı, uyarılabilirliği, amplitüd, patern ve süreleri 3 grup arasında karşılaştırıldı.

Bulgular: GKR'de bilateral R2 ve R2k yanıtlarının ortalama başlangıç latansları akatizi grubunda HBS hastalarına ve sağlıklı bireylere göre daha uzundu. İIR'de yanıtların ortalama latansları gruplar arasında benzerdi. Toplam İ́R saptananların oranı, akatizi ve HBS gruplarında sağlıklı bireylerle karşılaştırıldı $\breve{g} ı$ da daha yüksekti ve bu fark sınırda anlamlı bulundu $(\mathrm{p}=0,047)$. Akatizi grubunda işitme stimülasyonundan sonraki cevapların süresi daha uzundu. SSİ'nin varlığı ve latansı her üç grup arasında da benzerdi.

Sonuç: Akatizi grubunda İIR'de ortalama başlangıç latanslarının daha uzun ve uyarılabilirliğin daha yüksek olması, bu hastalardaki hipodopaminerjik durum ile ilişkilidir. Bunun yanı sıra akatizide saptadığımız uzun R2-GKR latanslar, bu yolakta gecikmiş transmisyonunun varlığını, dolaylı olarak da yapısal bir lezyon yokluğunda serotoninerjik yolakların da akatizinin mekanizmasında yer aldığını düşündürmektedir. Akatizide, HBS'den farklı olarak serotoninerjik tutulumun bulguları mevcutken, hipodopaminerjik bulgular HBS'li hastalarla oldukça benzerdir.

Anahtar Kelimeler: Akatizi, huzursuz bacaklar sendromu, beyin sapı refleksleri, göz kırpma refleksi, işitsel irkilme refleksi

Address for Correspondence/Yazışma Adresi: Bengi Gül Türk MD, Istanbul University Cerrahpasa Faculty of Medicine, Department of Neurology, Istanbul, Turkey Phone: +90 5374593766 E-mail: alpaslanbengigul@gmail.com ORCID ID: orcid.org/0000-0003-1839-5971

Received/Geliş Tarihi: 26.12.2017 Accepted/Kabul Tarihi: 04.04.2018

${ }^{\circ}$ Copyright 2018 by Turkish Neurological Society

Turkish Journal of Neurology published by Galenos Publishing House. 


\section{Introduction}

Akathisia is a movement disorder characterized by urge, inner restlessness, and a constant requirement to move the limbs (1). The general cause is neuroleptic drugs; however, it may appear without any drug use or any underlying disorder, or it may develop secondary to other systemic/neurologic disorders. The generation of symptoms after the use of neuroleptic drugs and the recovery of symptoms after discontinuation of these drugs support the role of striatal dopaminergic blockade in the etiology. Amelioration after the use of GABAergic drugs suggests that the GABAergic system may play a role in the pathogenesis. On the other hand, we previously hypothesized that the serotonin system could also be involved (2).

Akathisia and idiopathic restless legs syndrome (RLS) share some clinical features. RLS is characterized by sensory and/or motor symptoms that are relieved by movement and are more prominent in the late afternoon or in the evening (3). Apart from diurnal fluctuations, restlessness and crawling sensations are shared by akathisia, as first emphasized in 1961 (4). Since then, there has been different reports analyzing commonalities. Although the efficacy of clonazepam in RLS treatment has been controversial lately, complaints tend to improve in both diseases after GABAergic drugs such as clonazepam or gabapentin $(5,6)$. There exists polysomnographic evidence of periodic limb movements (PLMs) during sleep in neuroleptic-induced akathisia very similar to RLS, whereas patients receiving neuroleptic medications without symptomatology of akathisia had no PLMs $(5,7)$. Both disorders may coexist in the clinical course of Parkinson's disease or schizophrenia, and after the use of dopamine-blocking drugs $(8,9,10,11,12)$. There is also one case in the literature describing nocturnal akathisia; however, this case possibly represents RLS induced by clozapine, which was not discussed by the authors (13).

The presentation of RLS and akathisia in patients with brainstem involvement suggests that there may be an important role of the brainstem in the etiology (7). Here, we aimed to investigate the functional changes of the brainstem and its rostral connections in akathisia in comparison with RLS. For this purpose, we retrospectively performed an offline analysis of blink reflex (BR), auditory startle reflex (ASR) and startle responses to somatosensory startle (SSS) in groups of patients with akathisia and RLS.

\section{Materials and Methods}

Subjects: The data of seven patients with akathisia were included in the study. The data were obtained during another study (2) and the clinical features of the patients were reported in the previous study (2). Briefly, akathisia developed after the use of neuroleptic drugs and its diagnosis was based on the Diagnostic and Statistical Manual of Mental Disorders. The underlying disorders for neuroleptic use were schizophrenia $(n=5)$, psychotic depression $(n=1)$ and bipolar disorder $(n=1)$. All patients had been using dopamine receptor antagonist medications (quetiapine, olanzapine, clozapine, zuclopenthixol or amisulpride) before the onset of akathisia; three patients were also using selective serotonin reuptake inhibitors (SSRIs); and one patient was on valproic acid treatment. According to the Barnes Akathisia Rating Scale, akathisia was mild in two patients, moderate in three, and severe in two. We also included the data of a group of patients with RLS $(\mathrm{n}=14)$, which was diagnosed according to the International RLS Study Group criteria (14). Patients with RLS with any underlying disorders were excluded.

A control group was formed including healthy volunteers $(\mathrm{n}=39)$. Sex distribution and mean age were similar among groups (Table 1).

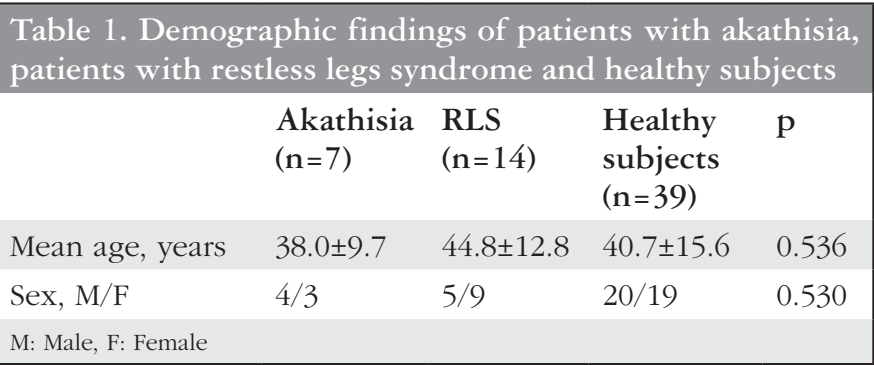

\section{Method}

Electrophysiologic assessments: A Neuropack Sigma MEB$5504 \mathrm{k}$ (Nihon Kohden Medical, Tokyo, Japan) was used to perform the electrophysiologic studies, using $\mathrm{Ag}-\mathrm{AgCl}$ surface electrodes. The evaluations were made in a quiet room within one month after the onset of akathisia.

BR: Recordings were performed over the orbicularis oculi (O.oc) according to standard methods (15) and repeated five times. The recordings were rectified and averaged. A $0.2 \mathrm{~ms}$ electrical stimulation of the supraorbital branch of the trigeminal nerve was used at the supraorbital notch. The analysis time was adjusted as $20 \mathrm{~ms} / \mathrm{div}$ and the amplitude sensitivity was 200-500 microV.

ASR: Recordings were made simultaneously over the unilateral O.oc, sternocleidomastoid (SCM), and biceps brachii (BB) muscles. A monophasic 100-ms auditory tone burst stimulus at an intensity of 105-dB hearing level was delivered bilaterally through earphones and was repeated eight times at random intervals of 2-5 min. We increased the stimulus duration by $50 \mathrm{~ms}$ for every two stimuli to prevent habituation. The ground electrode was positioned over the sternum. Single sweeps of $500 \mathrm{~ms}$ were recorded with filters at 10 and $10,000 \mathrm{~Hz}$ amplitude sensitivity.

Startle reflex to SSS: Recordings were performed over the O.oc, SCM, and BB muscles randomly as five consecutive bursts with a minimum interval of $20 \mathrm{~s}$ to prevent habituation. A single electrical stimulus with a duration of $0.2 \mathrm{~ms}$ and with an intensity twice the level that induced a supramaximal response over the hand was applied. The electrical stimulus was given percutaneously to the median nerve at the wrist. The filter settings were $10,000 \mathrm{~Hz}$ high-cut and $10-\mathrm{Hz}$ low-cut. The analysis time was adjusted as $20-50 \mathrm{~ms} / \mathrm{div}$, and the amplitude sensitivity was $200-500 \mu \mathrm{V}$.

The study were approved by the Uskudar University Ethics Committee for Non-invasive Research (date: 22.01.2018, protocol number: 01) and all participants gave informed consent.

\section{Statistical Analysis}

We measured the following parameters of each reflex study:

BR:

- Onset latency of R1, R2 and R2c,

- Amplitude of R2. 
ASR:

- Onset latency,

- Duration of each muscle response,

- Pattern,

- Probability of response,

- Total ASR probability.

For the calculation of total ASR probability and probability of response on each muscle, we used the following formulae, respectively: Total number of response/24x100 and response number on each muscle (O.oc, SCM, BB)/8x100.

Startle reflex to SSS:

- Presence of a response,

- Duration of each muscle response,

- Pattern.

Presence of a response was categorized as present or absent.

Data analyses were performed using the Statistical Package for the Social Sciences version 20. For numeric variables, three groups were compared using the Kruskal-Wallis test. Post hoc analysis was performed using the Mann-Whitney $U$ test when the distribution of data was non-homogenous and we performed the t-test for independent variables when the distribution was homogenous. Categorical variables were compared using the chi-square test. Spearman's rank-order correlation was used for correlation analysis between abnormal electrophysiologic findings and clinical features.

$\mathrm{p}<0.05$ was accepted as statistically significant.

\section{Results}

BR: Mean onset latencies of bilateral R2 and R2c were longer in the akathisia group compared with patients with RLS and healthy individuals (Figure 1A). Although the mean R2 amplitude in the akathisia group was similar to that in the RLS group, both groups had high-amplitude responses compared with healthy subjects (Figure 1B). The abnormal latencies in the akathisia group did not correlate with age and did not show a specific difference in patients with different severities of akathisia.

ASR: The mean latencies of responses after auditory stimulation were similar among the groups (Figure 1C). There was a trend for an increased probability of response over the SCM muscle after auditory stimulation among patients with akathisia; however, there was no statistically significant difference. The total ASR probability was higher in the akathisia and RLS groups compared with healthy subjects and this difference showed borderline significance $(\mathrm{p}=0.047$, Figure 1D). The Total ASR probability in akathisia was $51.3 \pm 15.0$. It was $50.0 \pm 12.5$ in the RLS group, whereas it was $43.1 \pm 9.0$ in healthy individuals. The duration of response over the O.oc and SCM muscles was longer in the akathisia group than those in patients with RLS and healthy subjects (Figure 1E). There was no correlation between age and abnormal ASR findings in akathisia patients. ASR findings were also similar between patients with varying akathisia severities.

Startle response to SSS: The presence and latency of SSS were similar among the three groups.

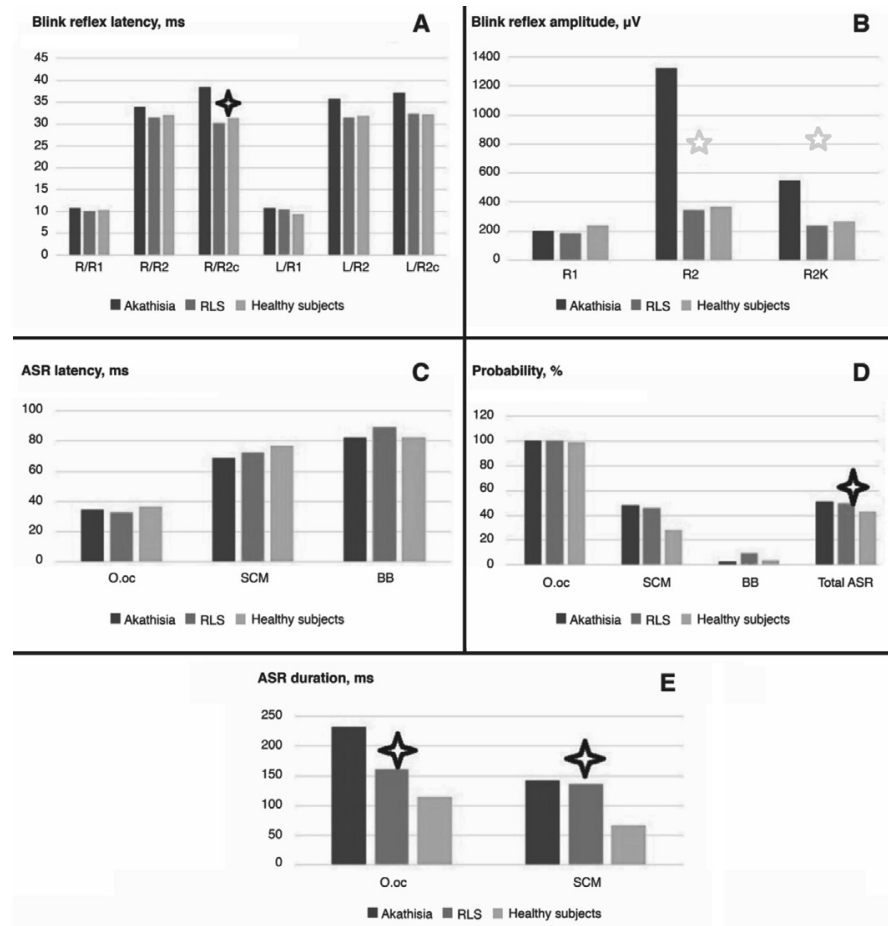

Figure 1. Graphic representation of mean values in patients with akathisia, patients with restless legs syndrome and healthy subjects. A) Mean blink reflex latency. B) Mean blink reflex amplitude. C, D and E) Mean auditory startle reflex latency, probability and duration (black star shows $\mathrm{p}<0.05$, gray star means $\mathrm{p}<0.005$ )

RLS: Restless legs syndrome

\section{Discussion}

The main results of our study were as follows: (i) longer onset latencies of BR-R2 and (ii) the increased duration of responses after auditory stimulation (ASR) in patients with akathisia compared with those with RLS and healthy subjects. Second, both the akathisia and RLS groups had higher R2 amplitudes than healthy individuals.

Brainstem reflexes are under the control of multiple suprasegmental systems, which are mediated by serotonin, dopamine or GABA. The $\mathrm{R} 1$ component of $\mathrm{BR}$ is mainly controlled by the pons. The R2 pathway is controlled by multiple synapses between the pons and the medulla oblongata. Use of neuroleptic drugs generally leads to reduced blinking frequency as well as high-amplitude R1 (16). However, prolonged latency has not yet been identified in the use of these drugs. Longer latencies have been reported in brainstem lesions, stimulation of the substantia nigra, and after administration of nicotine or D2 receptor agonists (apomorphine) (17) or serotonin antagonists (18). Theoretically, atypical antipsychotic drugs block the 5-HT receptors of serotonin, which may be responsible for the longer R2 latency in these patients. Smoking and thus nicotine consumption is high in patients with psychiatric problems. Although we do not have a group of psychiatric patients without the symptoms of akathisia, we believe that nicotine is not the sole cause of the prolongation of latencies in the akathisia group 
because nicotine leads to a longer BR response with lower amplitudes (17).

The BR-R2 amplitude denotes brainstem excitability. An increase in R2 amplitude shows increased excitability of the R2 circuit, which was previously demonstrated in patients with basal ganglia dysfunction as in Parkinson's disease, other types of parkinsonism syndromes, PLM disorders, and in a patient with RLS $(19,20,21,22)$. In our study, we found an increase in R2 amplitude in patients with RLS, similar to those found in previous studies. Similarly, in our study, there were also indications of increased R2 excitability among patients with akathisia, suggesting the presence of a hyperexcitability state in the brainstem among patients with akathisia, similar to RLS. It has been shown that D1 receptor super-sensitivity and dopamine deficiency are the underlying mechanism of RLS (23). Thus, we may suggest that a similar dopaminergic deficit may be present in akathisia.

Normal ASR and SSS patterns support the idea that the brainstem macrostructure is intact in both patient groups. It is known that ASRs show different responses in many diseases involving the basal ganglia. It is reported to be absent or reduced in progressive supranuclear palsy, whereas it is enhanced in Parkinson's disease and multiple system atrophy $(24,25,26,27,28,29,30)$. Previous studies have shown that the probability of ASR increases in patients with idiopathic RLS, which was attributed to disinhibition of reticulospinal pathways secondary to dopamine deficiency (30). We found a similarly enhanced ASR in patients with akathisia and RLS compared with healthy individuals, thus supporting dopaminergic deficiency in akathisia. Other possible causes for enhanced ASR were serotonin agonists, lesions of substantia nigra or anxiety. Neuroleptic drugs block several neurotransmitter pathways, they generally lead to serotonin antagonism and not agonism. As a matter of fact, serotonin receptor antagonists cause attenuation in the ASR (31). Thus, serotonin antagonism caused by neuroleptic drugs is an unlikely cause. In our patient group, there were no patients with cerebral lesions or anxiety disorders.

Startle reflex to SSS is also a defense response produced in the caudal brainstem. It has a connection with the upper brainstem and the spinal cord via the reticulobulbar and reticulospinal tracts. There were similar presence rates and latencies of SSS among the groups, suggesting intact reticulobulbar and reticulospinal tracts. However, we did not measure the amplitudes and durations of SSS responses, which is a limitation.

\section{Study Limitations}

There are some other limitations in this study. As mentioned above, a patient group using dopamine antagonists without exhibiting akathisia is lacking. Investigating patients using neuroleptic medications before the development of akathisia may further contribute to understanding its pathophysiology. The number of patients in each group was relatively small, meaning that some of the results only had borderline significance. The medications were heterogeneous and there were patients using SSRIs. Last, an analysis of smoking habits in the akathisia group would have been helpful.

\section{Conclusion}

In conclusion, the longer latencies of R2-BR and enhanced ASR in akathisia suggest involvement of serotoninergic pathways as well as dopaminergic pathways in akathisia. Findings suggestive of serotoninergic involvement differ from RLS, whereas findings attributed to dopaminergic deficits were quite similar to patients with RLS.

\section{Ethics}

Ethics Committee Approval: The study were approved by the Uskudar University Ethics Committee for Non-invasive Research (date: 22.01.2018, protocol number: 01).

Informed Consent: Consent form was filled out by all participants.

Peer-review: Externally peer-reviewed.

\section{Authorship Contributions}

Surgical and Medical Practices: B.G.T., A.G., S.M., B.M., D.K., M.E.K., Concept: B.G.T., A.G., S.M., B.M., D.K., M.E.K., Design: B.G.T., A.G., S.M., B.M., D.K., M.E.K., Data Collection or Processing: B.G.T., A.G., S.M., B.M., D.K., M.E.K., Analysis or Interpretation: B.G.T., A.G., S.M., B.M., D.K., M.E.K., Literature Search: B.G.T., A.G., S.M., B.M., D.K., M.E.K., Writing: B.G.T., A.G., S.M., B.M., D.K., M.E.K.

Conflict of Interest: No conflict of interest was declared by the authors.

Financial Disclosure: The authors declared that this study received no financial support.

\section{References}

1. Burke RE, Kang UJ, Jankovic J, Miller LG, Fahn S. Tardive akathisia: an analysis of clinical features and response to open therapeutic trials. Mov Disord 1989;4:157-175.

2. Metin B, Metin SZ, Gunduz A, et al. Brainstem reflexes are hyperactive in patients with drug induced akathisia. Neurol Sci 2017;38:1683-1689.

3. Walters AS. Restless legs syndrome and periodic limb movements in sleep. In: Guilleminault C. (ed). Clinical neurophysiology of sleep disorders. Stanford: Elsevier 2005:273-280.

4. Blom S, Ekbom KA. Comparison between akathisia developing on treatment with phenothiazine derivatives and the restless legs syndrome. Acta Med Scand 1961;170:689-694.

5. Inami Y, Horiguchi J, Nishimatsu O, et al. A polysomnographic study on periodic limb movements in patients with restless legs syndrome and neuroleptic-induced akathisia. Hiroshima J Med Sci 1997;46:133-141.

6. Sullivan MA, Wilbur R. Gabapentin pharmacotherapy for antipsychoticinduced akathisia: single-patient experiment and case report. Ther Adv Psychopharmacol 2014;4:100-102.

7. Walters A.S, Hening W, Rubinstein M, Chokroverty S. A clinical and polysomnographic comparison of neuroleptic-induced akathisia and the idiopathic restless legs syndrome. Sleep 1991;14:339-345.

8. Young WB, Piovesan EJ, Biglan KM. Restless legs syndrome and druginduced akathisia in headache patients, CNS. Spectr 2003;8:450-456.

9. Poewe W, Högl B. Akathisia, restless legs and periodic limb movements in sleep in Parkinson's disease. Neurology 2004;63:S12-16.

10. Kang SG, Lee HJ, Jung SW, et al. Characteristics and clinical correlates of restless legs syndrome in schizophrenia. Prog Neuropsychopharmacol Biol Psychiatry 2007;31:1078-1083.

11. Aggarwal S, Dodd S, Berk M. Restless leg syndrome associated with atypical antipsychotics: current status, pathophysiology, and clinical implications. Curr Drug Saf 2015;10:98-105.

12. Webb J. Co-occurring akathisia and restless legs syndrome likely induced by quetiapine. J Neuropsychiatry Clin Neurosci 2012;24:E46-47. 
13. Kyriakos D, Bozikas V.P, Garyfallos G, Lavrentiadis G, Giouzepas J, Fokas K Tardive nocturnal akathisia due to clozapine treatment. Int J Psychiatry Med 2005;35:207-211

14. American Academy of Sleep Medicine. International classification of sleep disorders, 3rd ed. Darien, IL: American Academy of Sleep Medicine, 2014.

15. Kimura J. Electrodiagnosis in Diseases of Nerve and Muscle: Principles and Practice. 4rd ed. Oxford University Press, 2013.

16. Bucher SF, Trenkwalder C, Oertel WH. Reflex studies and MRI in the restless legs syndrome. Acta Neurol Scand 1996;94:145-150.

17. Basso MA, Strecker RE, Evinger C. Midbrain 6-hydroxydopamine lesions modulate blink reflex excitability. Exp Brain Res 1993;94:88-96.

18. LeDoux MS, Lorden JF, Smith JM, Mays LE. Serotonergic modulation of eye blinks in cat and monkey. Neurosci Lett 1998;253:61-64.

19. Evinger C, Basso MA, Manning KA, Sibony PA, Pellegrini JJ, Horn AK. A role for the basal ganglia in nicotinic modulation of the blink reflex. Exp Brain Res 1993;92:507-515.

20. Kimura J. Disorder of interneurons in Parkinsonism. The orbicularis oculi reflex to paired stimuli. Brain 1973;96:87-96.

21. Napolitano A, Bonuccelli U, Rossi B. Different effects of levodopa and apomorphine on blink reflex recovery cycle in essential blepharospasm. Eur Neurol 1997;38:119-122.

22. Briellmann RS, Rösler KM, Hess CW. Blink reflex excitability is abnormal in patients with periodic leg movements in sleep. Mov Disord 1996;11:710714
23. Connor JR, Wang XS, Allen RP, Beard JL, Wiesinger JA, Felt BT, Earley CJ. Altered dopaminergic profile in the putamen and substantia nigra in restless leg syndrome. Brain 2009;132:2403-2412.

24. Vidailhet M, Rothwell JC, Thompson PD, Lees AJ, Marsden CD. The auditory startle response in the Steele-Richardson-Olszewski syndrome and Parkinson's disease. Brain 1992;115:1181-1192.

25. Valldeoriola F, Valls-Solé J, Tolosa E, Nobbe FA, Munoz JE, Marti J. The acoustic startle response is normal in patients with multiple system atrophy. Mov Disord 1997;12:697-700.

26. Kofler M, Müller J, Reggiani L, Wenning GK. Somatosensory evoked potentials in progressive supranuclear palsy. J Neurol Sci 2000;179:85-91.

27. Kofler M, Müller J, Wenning GK, et al. The auditory startle reaction in parkinsonian disorders. Mov Disord 2001;16:62-71.

28. Kofler M, Müller J, Seppi K, Wenning GK. Exaggerated auditory startle responses in multiple system atrophy: a comparative study of parkinson and cerebellar subtypes. Clin Neurophysiol 2003;114:541-547.

29. Müller J, Kofler M, Wenning GK, Seppi K, Valls-Solé J, Poewe W. Auditory startle response in cervical dystonia. Mov Disord 2003;18:1522-1526.

30. Birgit F, Wolfgang N. L, Birgit H, Werner P, Markus K. Auditory Startle Reaction is disinhibited in idiopathic Restless Legs Syndrome. Sleep 2007;30:489-493.

31. Curtin PC, Medan V, Neumeister H, Bronson DR, Preuss T. The 5-HT5A receptor regulates excitability in the auditory startle circuit: functional implications for sensorimotor gating. J Neurosci 2013;33:10011-10020. 